\title{
Natural killer cell-based therapies
}

\section{François Romagné ${ }^{1 *}$ and Eric Vivier ${ }^{2,3,4,5}$}

\author{
Addresses: ${ }^{1}$ Innate Pharma, 117 Avenue de Luminy - BP 30191, 13276 Marseille, CEDEX 09, France; ${ }^{2}$ Centre d'Immunologie de Marseille-Luminy, \\ Université de la Méditerranée UM 631, Campus de Luminy, Case 906, 13288 Marseille, CEDEX 09, France; ${ }^{3}$ INSERM UMR-S 631, Marseille, France; \\ ${ }^{4}$ CNRS, UMR 6102, Marseille, France; ${ }^{5}$ Assistance Publique - Hôpitaux de Marseille, Hôpital de la Conception, 13385 Marseille, France \\ * Corresponding author: François Romagné (francois.romagne@innate-pharma.fr) \\ Fl000 Medicine Reports 2011, 3:9 (doi:10.3410/M3-9) \\ This is an open-access article distributed under the terms of the Creative Commons Attribution-Non Commercial License \\ (http://creativecommons.org/licenses/by-nc/3.0/legalcode), which permits unrestricted use, distribution, and reproduction in any medium, \\ provided the original work is properly cited. You may not use this work for commercial purposes. \\ The electronic version of this article is the complete one and can be found at: http://f $1000 . c o m / r e p o r t s / m / 3 / 9$
}

\begin{abstract}
Allotransplantation of natural killer (NK) cells has been shown to be a key factor in the control and cure of at least some hematologic diseases, such as acute myeloid leukemia or pediatric acute lymphocytic leukemia. These results support the idea that stimulation of NK cells could be an important therapeutic tool in many diseases, and several such approaches are now in clinical trials, sometimes with conflicting results. In parallel, recent advances in the understanding of the molecular mechanisms governing NK-cell maturation and activity show that NK-cell effector functions are controlled by complex mechanisms that must be taken into account for optimal design of therapeutic protocols. We review here innovative protocols based on allotransplantation, use of NK-cell therapies, and use of newly available drug candidates targeting NK-cell receptors, in the light of fundamental new data on NK-cell biology.
\end{abstract}

\section{Introduction}

Natural killer (NK) cells are the front-line troops of the immune system that help to keep you alive while your body marshals a specific response to viruses or malignant cells. They constitute about $10 \%$ of circulating lymphocytes [1] and are on patrol constantly, always on the lookout for virus-infected or tumor cells, and when detected, they lock onto their targets and destroy them by inducing apoptosis while signaling danger by releasing inflammatory cytokines. By using NK cells that do not need prior exposure to their target, the innate immune system buys time for the adaptive immune system (T cells and B cells) to build up a specific response to the virus or tumor. Recent advances in understanding this process have led to the hope that NK cells could be harnessed as a therapy for cancers and other diseases, and we shall outline recent progress in understanding NK-cell biology that brings this approach into the realm of clinical trials.

Considerable advances have been made in understanding the molecular mechanisms governing NK-cell activation, which are assessed by the cells' ability to lyse different targets and/or secrete inflammatory cytokines such as interferon gamma (IFN- $\gamma$ ) when in their presence. NK-cell activation is the result of a switch in the balance between the positive and negative signals provided by two main types of receptors. The receptors NKG2D, NKp46, NKp30, NKp44, the activating form of KIR (killer cell immunoglobulin-like receptor), known as KIR-S, and CD16 provide positive signals, triggering toxicity and production of cytokines. Although some of the ligands of these receptors remain unknown, the discovery of NKG2D ligands (MICA and the RAET1 family) and the NKp30 ligand (B7H6) suggests that such receptors recognize molecules that are seldom present on normal cells but are induced during infection or carcinogenesis. It is worth noting that $\mathrm{CD} 16$ recognizes antibody-coated target cells through their Fc portion, the receptor that mediates antibody-dependent cellular cytotoxicity, an important mechanism of action of therapeutic monoclonal antibodies (mAbs). The function of KIR-S, a family of activating receptors with a lot of homology with inhibitory KIRs (KIR-L) including the sharing of some ligands, remains largely unknown. 
In the normal state of affairs, there are checks and balances to keep NK cells from attacking normal cells: activating ligands are rare on normal cells and there are inhibitory receptors on NK cells (Figure 1). The most studied inhibitory receptors are a family of immunoglobulin (Ig)-like receptors with two (KIR2DL1 and KIR2DL2/3) or three (KIR3DL1) Ig-like domains, and immunoreceptor tyrosine-based inhibition intracellular motifs (ITIMs), which transduce negative signals [2]. The ligands of these receptors are well characterized and each consist of large families of major histocompatibility complex (MHC) class I gene variants (alleles) sharing structural determinants. KIR2DL1 and KIR2DL2/3 molecules recognize MHC-C alleles with a lysine or an asparagine at position 80 (collectively termed C2 alleles and $\mathrm{C} 1$ alleles, respectively), whereas KIR3DL1 recognizes MHC-B alleles sharing a Bw4 epitope, representing about half of the overall MHC-B alleles. Another receptor, NKG2A, recognizes HLA-E, an MHC class I-like molecule, loaded mostly with peptides derived from other class I molecules [3]. The expression of these molecules is variegated, and an individual NK cell will express either one or several inhibitory receptors. In combination, these receptors are sensors of the presence of MHC class I molecules on target cells and inhibitors of
NK function. An integrated, although simplified, view of NK-cell activation is that NK cells quantitatively integrate positive and negative signals provided by cancer cells or infected cells, which express NK-stimulatory ligands de novo, while often down-modulating MHC class I to avoid detection by $\mathrm{T}$ cells.

There has been considerable interest in stimulation of NKcell activity in recent years because of genetic studies, both in preclinical and clinical settings, showing that it can increase tumor immunosurveillance and eradicate established hematological diseases such as acute myeloid leukemia (AML), as well as some viruses [4]. In mouse models, the expression of NK-stimulatory NKG2D ligands not only induces short-term rejection of tumors, but also induces a protective adaptive immune response [5]. Similarly, mice genetically deficient in NKG2D are more susceptible to spontaneous cancer than wild-type mice [6]. In humans, the development of allotransplantation, a clinical procedure involving transplantation of genetically nonidentical cells (routinely used in AML), shed light on the role of NK cells and particularly the role of inhibitory receptors in this process. For certain donor recipient pairs, genetic differences in MHC class I genes between the donor and the recipient cause the KIR-expressing cells

Figure I. Natural killer (NK) cell recognition strategies
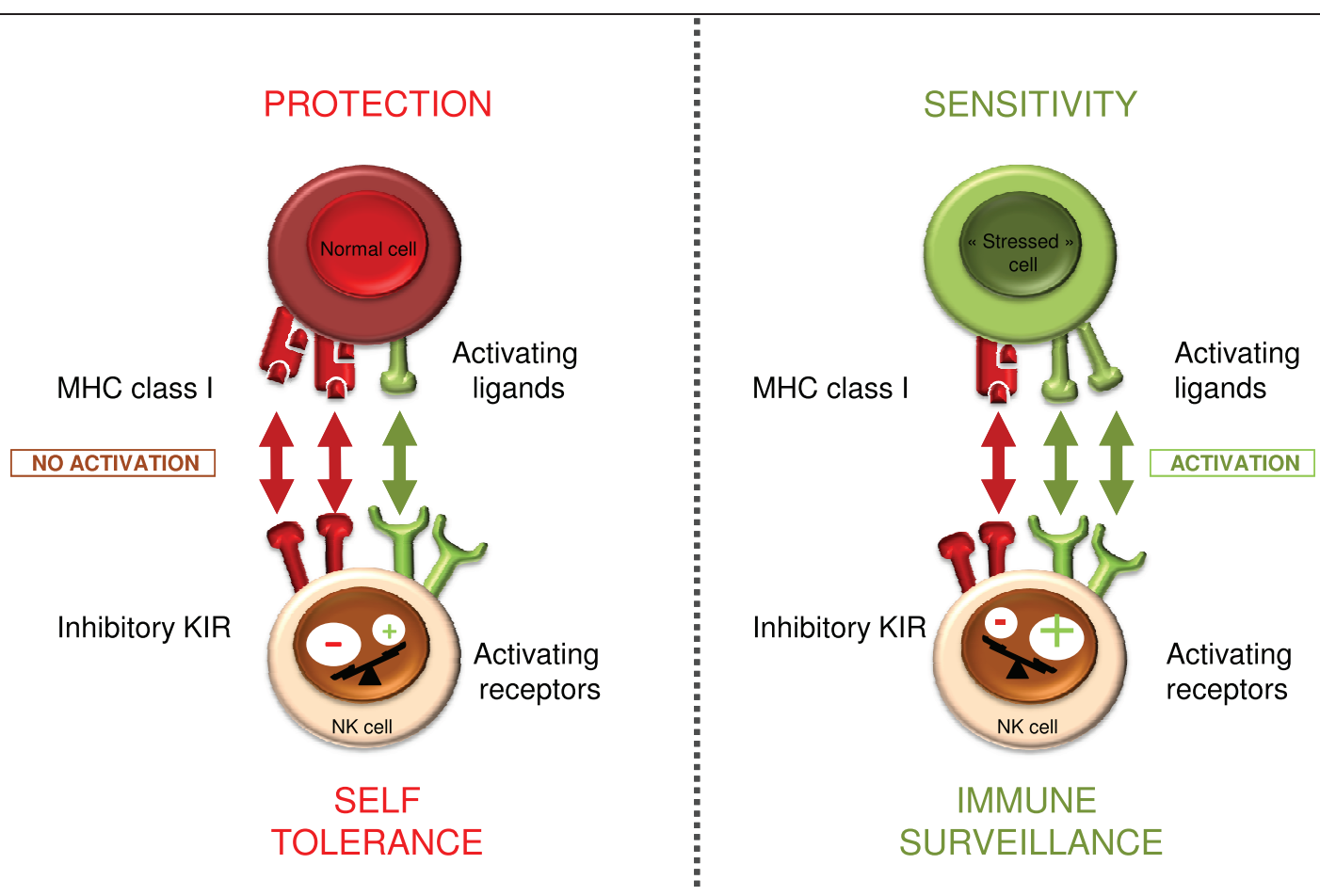

NK cells sense interacting cells via their activating and inhibitory receptors. The density of ligands for these receptors dictates whether or not this interaction will lead to NK-cell activation and hence cytotoxicity and/or cytokine secretion. MHC, major histocompatibility complex; KIR, killer cell immunoglobulin-like receptor. 
from the donor to not recognize their inhibitory MHC class I ligands in the recipient, leaving a subpopulation of donor NK cells free from inhibition, referred to as "alloreactive" NK cells. For example, a donor NK-cell subpopulation expressing only KIR2DL1 transplanted in C1/C1 homozygotes or KIR2DL2/3 NK cells transplanted in $\mathrm{C} 2 / \mathrm{C} 2$ individuals do not find their cognate inhibitory ligands and become alloreactive. In haploidentical MHCmismatched hematopoietic stem cell transplantation (HSCT) - a situation where one MHC haplotype is similar between donor and recipient whereas the other is fully mismatched-that absence of inhibition due to the KIRMHC incompatibility results in major differences in the clinical outcome [7-9]. Clinical benefit correlates with the presence in the recipient of these disinhibited alloreactive NK cells from the donor, which are effective against recipient tumor cells. In viral infections, particular combinations of NK-activating receptors or KIR and their ligands are protective. Presence of the activating receptor KIR3DS1 and its putative ligand HLABw4-I80 has been shown to be a key factor in preventing HIV infection from leading to full-blown AIDS [10-12]. In hepatitis C, KIR2DL3 homozygosity and HLA-C1 homozygosity are beneficial in both early eradication of infection and response to standard treatment (type I IFN + ribavirin) $[13,14]$. Homozygosity of KIR2DL3 and HLA-C1 alleles has been reported to lead to lower levels of NK inhibition than other pairs of KIR ligand combinations [15,16], suggesting that this underlies the enhanced response to hepatitis C. However, as KIR can also be expressed by some T-cell subsets, it remains to be firmly established whether NK cells are responsible for these effects. Nevertheless, the results of these studies suggest that we should extend the design of NK cell-based therapies to diseases other than cancer, such as infections and inflammation.

We will review here the recent advances that could help with the design of proper protocols and therapies and advance the use of NK cells in the clinic, starting with allotransplantation (transplantation between genetically different individuals of the same species). This will be followed by a discussion of the cell therapy procedures that are being developed, and the pharmacological agents that are currently or could be used in clinical trials to take advantage of the activity of NK cells.

\section{Lessons from transplantation}

Since the initial data from haploidentical HSCT, a number of retrospective studies in allostransplantation have been published, sometimes leading to differing clinical outcomes [17]. These conflicting results may be explained in the light of new findings in NK-cell physiology and maturation.
Initially, alloreactive NK cells were simply defined by having KIRs that were only incompatible with the host $\mathrm{MHC}$, and several studies have identified such alloreactive NK cells that are effective against AML blasts. However, it has been shown in normal mice that NK cells with only inhibitory receptors incompatible with self MHC class I alleles do arise physiologically (i.e., not after transplantation) but are partially functionally disabled [18]. Hence, NK cells undergo a complex maturation process that necessitates the interaction of their inhibitory receptors with their ligands, in order to be fully functional against class I negative cells (recognition of missing self; see [18] for review). The precise molecular mechanisms and localization of this process remain largely unknown in mice but were shown to be dynamic and reversible $[19,20]$. It has since been confirmed in humans that NK cells with only MHCincompatible KIR cells do exist in normal individuals but, as in mice, they are partially functionally disabled [21-22], indicating that human NK cells also undergo education much like mouse NK cells. This leads to a revision of the concept of alloreactivity: KIR mismatch is necessary to induce activity against MHC-positive cells (we will refer to these cells as potentially alloreactive) but not entirely sufficient, as they must have undergone an education process. It follows that functional assays must be performed to demonstrate activity and define truly alloreactive cells.

These new findings may lead to reconciliation of the conflicting data from allogeneic HSCT. Allogeneic HSCT (from a nonidentical donor) is a complex clinical procedure, with considerable differences in the nature and origin of the graft, as well as in pregraft treatments (conducted to remove recipient hematopoietic cells and thereby allow the graft to implant) and postgraft treatments (to prevent graft-versus-host disease [GVHD] caused by donor T cells). Generally, there are two main scenarios. In the first, haploidentical grafts consisting of high doses of highly purified donor CD34positive hematopoietic stem cells, with very few mature cells, are injected after very intense conditioning regimens of the host to avoid graft rejection (there is virtually no postgraft treatment as the graft is highly T cell-depleted) (Figure 2). Truly alloreactive NK cells have been consistently found ex vivo following such transplantation, in an activated state resulting from missing-self recognition, and this scenario is associated with an improved clinical outcome [23]. Unfortunately, such haploidentical procedures also require profound immunosuppression of the host, and the treatmentrelated morbidities caused by infection are high, so such procedures are not used widely. In the second scenario, allogeneic HSCT can be matched except at a given HLA-B 
Figure 2. Natural killer (NK) cell-based therapies

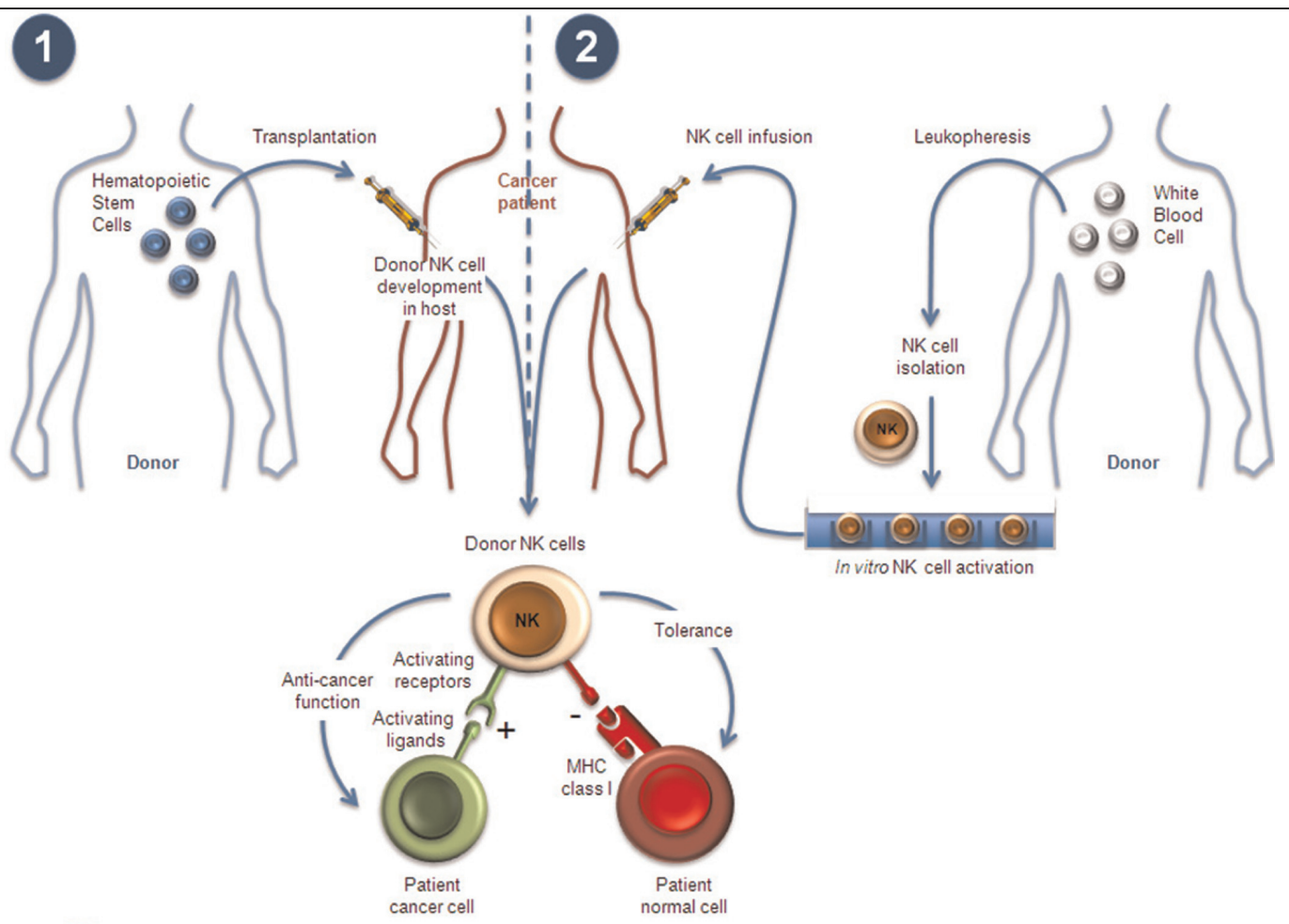

3

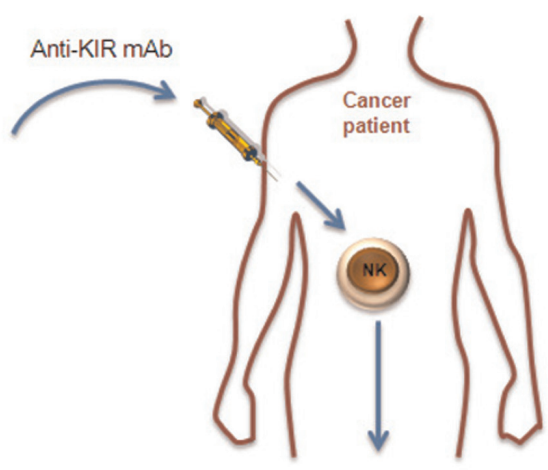

Patient NK cells

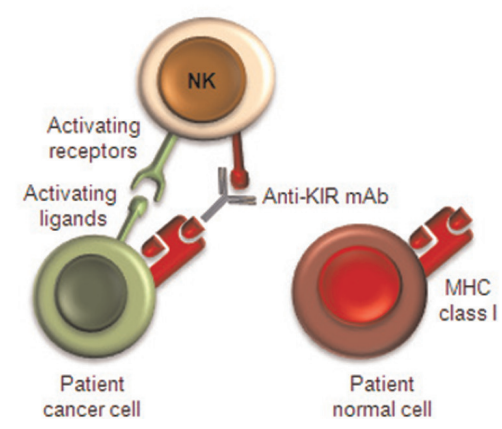

NK-cell recognition strategies can be manipulated in the context of hematopoietic stem cell transplantation (HSCT); (I) and (2) by infusion of pure, activated NK-cell preparation and (3) by administration of antiKIR monoclonal antibodies (mAbs) (see text). MHC, major histocompatibility complex; $\mathrm{KIR}$, killer cell immunoglobulin-like receptor. 
or HLA-C allele, and require much less conditioning pregraft, but more immunosuppressive treatment postgraft to avoid GVHD. Such protocols vary widely depending on the laboratories, both in terms of pregraft and postgraft treatments and cell content in the graft (mature cell content and origin of graft consisting of either bone marrow cells or mobilized peripheral cells). Not surprisingly, such protocols vary widely in the KIR mismatch effect, with outcomes to match: beneficial, neutral, or even pejorative. Taking into account the new findings on NK-cell physiology, the current prevailing hypothesis is that in haploidentical HSCT, the harsh conditioning regimen and high CD34-positive cell content allow the donor NK cells to mature with a recognition of the "self" MHC type on the donor hematopoietic cells, and therefore become truly alloreactive against residual recipient blast cells, whereas normal host tissues are spared because of lack of NK-stimulatory ligand expression [24,25]. In nonhaploidentical situations, education of NK cells on donor HLA may be lacking in some graft preparation and pregraft regimens, which might account for the neutral effects seen (cells remain potentially alloreactive). Conflicting results in nonhaploidentical situations [26,27] may be also explained by different treatments resulting in different T-cell levels in grafts and consequently different levels of GVHD [28]. This hypothesis is further supported by protocols where the graft origin is cord blood, a situation with few mature T cells in the graft, which results in a beneficial outcome [29].

In truly matched transplantation, there are no obvious reasons for alloreactive cells to develop as the MHC of donor and recipient are the same and the maturation of NK cells should spare all host cells (either normal or NK-stimulating ligand-expressing cells). Surprisingly, even in completely MHC-matched transplantation, in particular in T-depleted grafts, functionally alloreactive NK cells have been reported, with an improved outcome for patients homozygous for HLA-C1 or HLA-C2, for example [30,31]. In the same vein, it has been recently demonstrated in a large retrospective study that the KIR genotype alone influences clinical outcome, with the presence of KIR2DL3 and/or absence of KIR2DL2 and KIR2DS2 being less favorable, opening the way for the selection of donors based on KIR genotype in matched allotransplantation [32]. The functional basis of such observations is still incompletely understood: during NK-cell reconstitution from stem cells, KIR expression is variegated, and potentially alloreactive cells appear, but, as mentioned above, if such reconstitution was equivalent to normal NK-cell maturation, they should be functionally impaired and tolerant to self. It is possible that during hematopoietic reconstitution and in certain allograft protocols, the cytokine milieu, strength of inhibitory interaction and presence of different activating genes (depending on KIR genotype), and absence of $\mathrm{T}$-cell interaction ( $\mathrm{T}$ cell-depleted grafts) favor the maturation of truly alloreactive NK cells despite the presence of matched inhibitory receptors. Indeed, new studies describing NK-cell maturation point to the fact that the hyporesponsiveness of NK cells is very subtle and malleable, influenced by cytokines and probably genotype, and reversible $[19,20]$.

In summary, although many studies strongly suggest the efficacy of KIR-mismatched NK cells, definitive studies are needed to optimize the clinical settings. We need a better understanding of NK-cell development and function after matched allogeneic transplantation, depending on the specific allotransplantation protocol used, to take full advantage of the alloreactive potential of NK cells.

\section{Cell therapy protocols in development}

The current view arising from the results of allotransplantation studies is that NK cells, and particularly allogeneic KIR-mismatched NK cells, are effective, at least in adult AML and pediatric acute lymphocytic leukemia, but that the effect may depend on NK-cell maturation/ activation state. One way to better control NK-cell functional status (as well as the ratio of NK cells to target cells) would be to generate large quantities of these cells in vitro and inject them either as a therapeutic regimen alone or after allotransplantation.

Historically, crude, short-term (1-2 days) interleukin (IL)-2-activated cells were used as graft material (lymphokine-activated killer [LAK] cells), and although this was enriched in NK cells, the LAK cells were mostly T cells, and the cellular content was poorly defined and variable (see [33] for review). Initial attempts to work with purified preparations of NK cells led to promising results, although with a limited number of patients. Autologous HSCT followed by injection of purified, short-term IL-2-stimulated KIR-mismatched NK cells in multiple myeloma patients destroyed multiple myeloma blasts in vitro, did not lead to graft failure, and the NK cells survived at least a few days [34]. In a protocol not involving HSCT, purified short-term IL-2-activated haploidentical NK cells were injected into AML and other hematologic cancer patients after mild conditioning to avoid rejection of injected NK cells. This study showed that injected NK cells survived in the host for a few days and were well tolerated [35]. Although the number of patients is still too limited to draw firm conclusions, encouraging clinical signs of activity were seen in the above protocols. As neither protocol reached any doselimiting toxicity, these findings suggest that it may be 
possible to inject higher cell numbers if cell sources or ex vivo expansion procedures improve.

These initial results have prompted several groups to embark on the large-scale expansion of highly purified, GMP ("good manufacturing practice") grade NK cells after longer-term in vitro expansion. NK-cell purification by magnetic beads is followed by IL-2 expansion with or without feeder cells. Protocol for generation of single KIR-positive cells has also been designed but is not yet ready to be applied to large-scale clinical trials [36]. Functional studies using NK cells against leukemic cells or NK infusion in xenogenic models have demonstrated, however, that the cells generated are very active. Some of the protocols have reached smallscale phase I clinical trials and have demonstrated that high numbers of these infused NK cells are safe in humans $[37,38]$.

The current caveats of such protocols are the complexity of the procedures required, which would make it difficult to increase the scale-up to multicenter clinical studies necessary for larger phase II trials. Indeed, successful transfer of cell therapy protocols (compliant with regulatory standards) to industry and large clinical trials requires a centralized cell culture factory and the use of frozen cells. NK-cell culture protocols do not yet meet this benchmark, but further refinements should solve these issues [39]. Moreover, alloreactive NK cells should be the most potent cells in cell therapy protocol and their source can be a problem outside the context of allotransplantation. This alone may prevent the use of such cells in larger trials. The development of antiKIRtherapeutic mAbs (see below and Figure 2) that block NK inhibition may allow the use of autologous cells as an easier source of cell material, by inducing alloreactivity of NK cells that would otherwise be MHCtolerant.

Another important problem to be solved is the fate of ex-vivo expanded NK cells after infusion. Indeed, if NK cells from allogeneic donors are used, they may be rejected by the host immune system despite the mild immunosuppression used in some protocols. Even in cases of autologous transplantation or allotransplantation where donor NK cells are not rejected, they may be short lived, and protocols usually involve daily injection of IL-2 to sustain NK levels and activation status [34,35]. IL-2 injection may increase NK-cell lifespan and activity (although it has not been formally tested, by comparison with untreated cells) but also can generate outgrowth of Treg cells that may hamper the overall response to the tumor as shown in pilot clinical trials $[37,40]$. The very recent availability of GMP grade IL-15, now in phase I clinical trials by the National Institutes of Health (NIH) [40] may circumvent the use of IL-2, providing a better activation signal for NK cells, both in vitro and in vivo, without promoting Treg expansion.

\section{Pharmacological agents in development to modulate NK activity}

Although cell therapy protocols can be very useful to characterize NK-cell activity and, if successful, can translate into commercially available products, they remain very difficult and costly to develop on a large scale. It should be easier to move new drugs forward now that therapeutic agents are being tested that aim to stimulate NK-cell activity.

The most advanced compound specifically targeting NK cells is a blocking antiKIR mAb. This mAb, 1-7F9, recognizes KIR2DL1, 2, and 3 and therefore blocks the inhibition imposed by virtually all MHC class I C alleles, allowing it to be tested in all patients whatever their KIR and HLA genotypes. Building on the results of allotransplantation in AML and multiple myeloma patients [41], as well as preclinical data showing reconstitution of NK-cell lysis of MHC-positive multiple myeloma and AML blasts in vitro and in preclinical models [42], clinical trials with 1-7F9 mAb in both diseases have been initiated. Phase I results showed good tolerability in both scenarios (Vey et al., manuscript in preparation), paving the way for phase II trials that are now ongoing. While the monoclonal 1-7F9 should be valuable to block the inhibition of NK cells, other products are now available that can enhance the activation of NK cells. One of the most promising of these is IL-15, which is a key cytokine for NK cells.

In the same vein, it has been shown by several groups that certain drugs, already available in the therapeutic arsenal, can increase the expression of NK-activating ligands on the tumor, and therefore increase NK tumor lysis in vivo. Initially, it was shown that some chemotherapy (5-FU, Ara-C, cisplatin) and radiation or ultraviolet therapy targeting the DNA damage pathway can increase expression of the NK-stimulating ligand NKG2D on tumor cells, and lead to enhanced NK lysis of tumors [43]. More recently, new drugs targeting proteasome inhibitors, such as bortezomib, which is now registered for the treatment of multiple myeloma, have also been shown to induce NK-stimulatory ligands $[44,45]$. Finally, lenalidomide (Revlimid), a drug which has been shown to be active in multiple myeloma and to have promising preliminary results in other hematological malignancies, has been shown, in addition to having a direct antitumor effect, to upregulate NK-cell function through induction of cytokines [46] and to induce NK-stimulatory ligands on tumor cells. 
Some of these drugs, such as bortezomib or chemotherapies $[47,48]$, can also have inhibitory effects on NK cells so their use must be carefully evaluated, but their clinical availability opens the door to multiple combination possibilities, either sequentially or concomitantly, with cell therapy and antiKIR antibodies. Such combinations are beginning to be tested in the clinic (phase I/II for antiKIR in combination with lenalidomide, and cell therapies in combination with bortezomib [39]).

\section{Future directions}

Since the initial demonstration that NK-cell therapies are effective in some contexts, there has been a lot of progress in refining protocols, as well as new approaches such as the injection of highly purified, functionally controlled NK cells. Also, new drugs allow the in-vivo manipulation of NK cells by targeting their inhibitory receptors or activating receptors (through drugs driving the expression of ligands of activating receptors on tumor cells). All these tools have now been developed to a point where they can be tested in clinical trials either alone or in combination. Because recent advances have increased our understanding of NK maturation and function, such clinical trials can now be monitored for NK-cell activity and represent attractive possibilities to be translated into successful treatments in the clinic.

\section{Abbreviations}

AML, acute myeloid leukemia; GMP, good manufacturing practice; GVHD, graft-versus-host disease; HSCT, hematopoietic stem cell transplantation; IFNy, interferon gamma; Ig, immunoglobulin; IL, interleukin; KIR, killer cell immunoglobulin-like receptor; LAK, lymphokine-activated killer; $\mathrm{mAb}$, monoclonal antibody; MHC, major histocompatibility complex; MICA, MHC class Irelated chain A; NK, natural killer; RAET1, retinoic acid early transcripts- 1 .

\section{Competing interests}

FR and EV are co-founders and shareholders of Innate Pharma.

\section{Acknowledgements}

The authors thank Corinne Beziers-Lafosse (CIML) for excellent graphic assistance and CIML's antibody and cytometry facilities. EV's lab is supported by grants from the European Research Council (ERC advanced grants), Agence Nationale de la Recherche (ANR), Ligue Nationale Contre le Cancer (Equipe labellisée 'La Ligue'), as well as by institutional grants from INSERM, CNRS, and Université de la Méditerranée to the CIML. EV is a scholar from the Institut Universitaire de France.

\section{References}

I. Vivier E, Raulet DH, Moretta A, Caligiuri MA, Zitvogel L, Lanier LL, Yokoyama WM, Ugolini S: Innate or adaptive immunity? The example of natural killer cells. Science 20I I, 33 I:44-49.

2. Vivier E, Nunès JA, Vély F: Natural killer cell signaling pathways. Science 2004, 306:1517-9.

3. Parham P: MHC class I molecules and KIRs in human history, health and survival. Nat Rev Immunol 2005, 5:20I-I4.

4. Terme M, Ullrich E, Delahaye NF, Chaput N, Zitvogel L: Natural killer cell-directed therapies: moving from unexpected results to successful strategies. Nature Immunol 2008, 9:486-94.

5. Diefenbach A, Jensen ER, Jamieson AM, Raulet DH: Rael and $\mathbf{H 6 0}$ ligands of the NKG2D receptor stimulate tumour immunity. Nature 200I, 4I3:165-7I.

FI000 Factor 14

Evaluated by Wayne Yokoyama 05 Oct 200I, Eric Long 10 Oct 200I, William Heath 18 Oct 200I, Siamak Bahram 23 Nov 200I

6. Guerra N, Tan YX, Joncker NT, Choy A, Gallardo F, Xiong N, Knoblaugh S, Cado D, Greenberg NM, Raulet DH: NKG2Ddeficient mice are defective in tumor surveillance in models of spontaneous malignancy. Immunity 2008, 28:57I-80.

FI000 Factor 10

Evaluated by Glenn Dranoff I 5 Apr 2008, Lutz Walter 20 May 2008

7. Ruggeri L, Capanni M, Urbani E, Perruccio K, Shlomchik WD, Tosti A, Posati S, Rogaia D, Frassoni F, Aversa F, Martelli MF, Velardi A: Effectiveness of donor natural killer cell alloreactivity in mismatched hematopoietic transplants. Science 2002, 295:2097-100

FI000 Factor 10

Evaluated by John Cambier 21 Jun 2002

8. Ruggeri L, Mancusi A, Capanni M, Urbani E, Carotti A, Aloisi T, Stern M, Pende D, Perruccio K, Burchielli E, Topini F, Bianchi E, Aversa F, Martelli MF, Velardi A: Donor natural killer cell allorecognition of missing self in haploidentical hematopoietic transplantation for acute myeloid leukemia: challenging its predictive value. Blood 2007, I I 0:433-40.

FI000 Factor 6

Evaluated by Frank Christiansen 03 Jul 2007

9. Ruggeri L, Capanni M, Casucci M, Volpi I, Tosti A, Perruccio K, Urbani E, Negrin RS, Martelli MF, Velardi A: Role of natural killer cell alloreactivity in HLA-mismatched hematopoietic stem cell transplantation. Blood 1999, 94:333-9.

10. Alter G, Martin MP, Teigen N, Carr WH, Suscovich TJ, Schneidewind A, Streeck H, Waring M, Meier A, Brander C, Lifson JD, Allen TM, Carrington M, Altfeld M: Differential natural killer cell-mediated inhibition of HIV-I replication based on distinct KIR/HLA subtypes. J Exp Med 2007, 204:3027-36.

II. Alter G, Rihn S, Walter K, Nolting A, Martin M, Rosenberg ES, Miller JS, Carrington M, Altfeld M: HLA class I subtype-dependent expansion of KIR3DSI+ and KIR3DLI+ NK cells during acute human immunodeficiency virus type I infection. J Virol 2009, 83:6798-805.

12. Carrington M, Martin MP, van Bergen J: KIR-HLA intercourse in HIV disease. Trends Microbiol 2008, I 6:620-7.

13. Khakoo SI, Thio CL, Martin MP, Brooks CR, Gao X, Astemborski J, Cheng J, Goedert J], Vlahov D, Hilgartner M, Cox S, Little AM, Alexander GJ, Cramp ME, O'Brien SJ, Rosenberg WM, Thomas DL, Carrington M: HLA and NK cell inhibitory receptor genes in resolving hepatitis $\mathbf{C}$ virus infection. Science 2004, 305:872-4.

FI000 Factor 10

Evaluated by Eric Long 16 Aug 2004, Lewis Lanier 17 Aug 2004

14. Vidal-Castiñeira JR, López-Vázquez A, Díaz-Peña R, Alonso-Arias R, Martínez-Borra J, Pérez R, Fernández-Suárez J, Melón S, Prieto J, Rodrigo L, López-Larrea C: Effect of killer immunoglobulin-like 
receptors in the response to combined treatment in patients with chronic hepatitis $C$ virus infection. J Virol 2010, 84:475-8I.

15. Ahlenstiel G, Martin MP, Gao X, Carrington M, Rehermann B: Distinct KIR/HLA compound genotypes affect the kinetics of human antiviral natural killer cell responses. J Clin Invest 2008, I | 8: 1017-26.

16. Moesta AK, Norman PJ, Yawata M, Yawata N, Gleimer M, Parham P: Synergistic polymorphism at two positions distal to the ligand-binding site makes KIR2DL2 a stronger receptor for HLA-C than KIR2DL3. J Immunol 2008, I 80:3969-79.

17. Witt CS: The influence of NK alloreactivity on matched unrelated donor and HLA identical sibling haematopoietic stem cell transplantation. Curr Opin Immunol 2009, 21:53 I-7.

18. Raulet DH, Vance RE: Self-tolerance of natural killer cells. Nat Rev Immunol 2006, 6:520-3I.

19. Elliott JM, Wahle JA, Yokoyama WM: MHC class I-deficient natural killer cells acquire a licensed phenotype after transfer into an MHC class I-sufficient environment. J Exp Med 2010, 207:2073-9.

20. Joncker NT, Shifrin N, Delebecque F, Raulet DH: Mature natural killer cells reset their responsiveness when exposed to an altered MHC environment. J Exp Med 2010, 207:2065-72.

21. Anfossi N, André P, Guia S, Falk CS, Roetynck S, Stewart CA, Breso V, Frassati C, Reviron D, Middleton D, Romagné F, Ugolini S, Vivier E: Human NK cell education by inhibitory receptors for MHC class I. Immunity 2006, 25:33 I-42.

22. Cooley S, Xiao F, Pitt M, Gleason M, McCullar V, Bergemann TL, McQueen KL, Guethlein LA, Parham P, and Miller JS: A subpopulation of human peripheral blood NK cells that lacks inhibitory receptors for self-MHC is developmentally immature. Blood 2007, I | 0:578-86.

23. Moretta L, Locatelli F, Pende D, Marcenaro E, Mingari MC, Moretta A: Killer Ig-like receptor-mediated control of natural killer cell alloreactivity in haploidentical hematopoietic stem cell transplantation. Blood 2010, I I 7:764-7I.

24. Pende D, Marcenaro S, Falco M, Martini S, Bernardo ME, Montagna D, Romeo E, Cognet C, Martinetti M, Maccario R, Mingari MC, Vivier E, Moretta L, Locatelli F, Moretta A: Anti-leukemia activity of alloreactive NK cells in KIR ligand-mismatched haploidentical HSCT for pediatric patients: evaluation of the functional role of activating KIR and redefinition of inhibitory KIR specificity. Blood 2009, I |3:3 | | 9-29.

25. Haas $\mathrm{P}$, Loiseau $\mathrm{P}$, Tamouza R, Cayuela JM, Moins-Teisserenc $H$, Busson M, Henry G, Falk CS, Charron D, Socie G, Toubert A, Dulphy N: NK-cell education is shaped by donor HLA genotype after unrelated allogeneic hematopoietic stemcell transplantation. Blood 2010, I I7:1021-9.

26. Giebel S, Locatelli F, Lamparelli T, Velardi A, Davies S, Frumento G, Maccario R, Bonetti F, Wojnar J, Martinetti M, Frassoni F, Giorgiani G, Bacigalupo A, Holowiecki J: Survival advantage with KIR ligand incompatibility in hematopoietic stem cell transplantation from unrelated donors. Blood 2003, 102:8|4-9.

27. Davies SM, Ruggieri L, DeFor T, Wagner JE, Weisdorf DJ, Miller JS, Velardi A, Blazar BR: Evaluation of KIR ligand incompatibility in mismatched unrelated donor hematopoietic transplants. Killer immunoglobulin-like receptor. Blood 2002, 100:3825-7.

28. Cooley S, Trachtenberg E, Bergemann TL, Saeteurn K, Klein J, Le CT, Marsh SG, Guethlein LA, Parham P, Miller JS, Weisdorf DJ: Donors with group $B$ KIR haplotypes improve relapse-free survival after unrelated hematopoietic cell transplantation for acute myelogenous leukemia. Blood 2009, I | 3:726-32.

29. Willemze R, Rodrigues CA, Labopin M, Sanz G, Michel G, Socié G, Rio B, Sirvent A, Renaud M, Madero L, Mohty M, Ferra C, Garnier F, Loiseau P, Garcia J, Lecchi L, Kögler G, Beguin Y, Navarrete C, Devos T, lonescu I, Boudjedir K, Herr AL, Gluckman E, Rocha V; Eurocord-Netcord and Acute Leukaemia Working Party of the EBMT: KIR-ligand incompatibility in the graft-versus-host direction improves outcomes after umbilical cord blood transplantation for acute leukemia. Leukemia 2009, 23:492-500.
30. Yu J, Venstrom JM, Liu XR, Pring J, Hasan RS, O'Reilly RJ, Hsu KC: Breaking tolerance to self, circulating natural killer cells expressing inhibitory KIR for non-self HLA exhibit effector function after $\mathbf{T}$ cell-depleted allogeneic hematopoietic cell transplantation. Blood 2009, I | 3:3875-84.

31. Sobecks RM, Ball EJ, Maciejewski JP, Rybicki LA, Brown S, Kalaycio M, Pohlman B, Andresen S, Theil KS, Dean R, Bolwell B]: Survival of AML patients receiving HLA-matched sibling donor allogeneic bone marrow transplantation correlates with HLACw ligand groups for killer immunoglobulin-like receptors. Bone Marrow Transplant 2007, 39:4I7-24.

32. Cooley S, Weisdorf DJ, Guethlein LA, Klein JP, Wang T, Le CT, Marsh SEG, Geraghty D, Spellman S, Haagenson MD, Ladner M, Trachtenberg E, Parham P, Miller JS: Donor selection for natural killer cell receptor genes leads to superior survival after unrelated transplantation for acute myelogenous leukemia. Blood 2010, I | 6:24II-9.

33. Suck G, Koh MB: Emerging natural killer cell immunotherapies: large-scale ex vivo production of highly potent anticancer effectors. Hematol Oncol Stem Cell Ther 3:135-42.

34. Shi J, Tricot G, Szmania S, Rosen N, Garg TK, Malaviarachchi PA, Moreno A, Dupont B, Hsu KC, Baxter-Lowe LA, Cottler-Fox M, Shaughnessy JD Jr., Barlogie B, van Rhee F: Infusion of haploidentical killer immunoglobulin-like receptor ligand mismatched NK cells for relapsed myeloma in the setting of autologous stem cell transplantation. $\mathrm{Br} J$ Haematol 2008 |43:64|-53.

35. Miller JS, Soignier Y, Panoskaltsis-Mortari A, McNearney SA, Yun GH, Fautsch SK, McKenna D, Le C, Defor TE, Burns L], Orchard PJ, Blazar BR, Wagner JE, Slungaard A, Weisdorf DJ, Okazaki IJ, McGlave PB: Successful adoptive transfer and in vivo expansion of human haploidentical NK cells in patients with cancer. Blood 2005, 105:3051-7.

36. Siegler U, Meyer-Monard S, Jörger S, Stern M, Tichelli A, Gratwohl A, Wodnar-Filipowicz A, Kalberer CP: Good manufacturing practice-compliant cell sorting and large-scale expansion of single KIR-positive alloreactive human natural killer cells for multiple infusions to leukemia patients. Cytotherapy 2010, 12:750-63.

37. Barkholt L, Alici E, Conrad R, Sutlu T, Gilljam M, Stellan B, Christensson B, Guven $H$, Bjorkstrom NK, Söderdahl G, Cederlund K, Kimby E, Aschan J, Ringdén O, Ljunggren HG, Dilber MS: Safety analysis of ex vivo-expanded NK and NKlike $\mathbf{T}$ cells administered to cancer patients: a phase I clinical study. Immunotherapy 2009, I:753-64.

38. Fujisaki H, Kakuda H, Shimasaki N, Imai C, Ma J, Lockey T, Eldridge P, Leung WH, Campana D: Expansion of highly cytotoxic human natural killer cells for cancer cell therapy. Cancer Res 2009, 69:4010-7.

39. Berg M, Lundqvist A, McCoy P Jr., Samsel L, Fan Y, Tawab A, Childs R: Clinical-grade ex vivo-expanded human natural killer cells up-regulate activating receptors and death receptor ligands and have enhanced cytolytic activity against tumor cells. Cytotherapy 2009, I I:34|-55.

40. Geller MA, Cooley S, Judson PL, Ghebre R, Carson LF, Argenta PA, Jonson AL, Panoskaltsis-Mortari A, Curtsinger J, McKenna D, Dusenbery K, Bliss R, Downs LS, Miller JS: A phase II study of allogeneic natural killer cell therapy to treat patients with recurrent ovarian and breast cancer. Cytotherapy $20 \mathrm{II}$, 13:98-107.

4I. ClinicalTrials.gov - A phase I study of intravenous recombinant human IL-I 5 in adults with refractory metastatic malignant melanoma and metastatic renal cell cancer. [http://clinicaltrials. gov/ct2/show/NCT01021059?term=NCT0102 I 059\&rank=I]

42. Kröger N, Shaw B, lacobelli S, Zabelina T, Peggs K, Shimoni A, Nagler A, Binder T, Eiermann T, Madrigal A, Schwerdtfeger R, Kiehl M, Sayer HG, Beyer J, Bornhäuser M, Ayuk F, Zander AR, Marks DI; Clinical Trial Committee of the British Society of Blood and Marrow Transplantation and the German Cooperative Transplant Group: Comparison between antithymocyte globulin and alemtuzumab and the possible impact of KIR-ligand 
mismatch after dose-reduced conditioning and unrelated stem cell transplantation in patients with multiple myeloma. $\mathrm{Br} J$ Haematol 2005, 129:631-43.

43. Romagné $F$, André $P$, Spee $P$, Zahn $S$, Anfossi N, Gauthier L, Capanni M, Ruggeri L, Benson DM Jr., Blaser BW, Della Chiesa M, Moretta A, Vivier E, Caligiuri MA, Velardi A, Wagtmann N: Preclinical characterization of I-7F9, a novel human antiKIR receptor therapeutic antibody that augments natural killer-mediated killing of tumor cells. Blood 2009, I I 4:2667-77.

44. Gasser S, Orsulic S, Brown EJ, Raulet DH: The DNA damage pathway regulates innate immune system ligands of the NKG2D receptor. Nature 2005, 436: I |86-90.

FI000 Factor 17

Evaluated by Lewis Lanier I4 Jul 2005, Lucio Comai I8 Jul 2005, Guy Laurent 08 Aug 2005, Mark Smyth 12 Aug 2005, John Abrams 26 Aug 2005, Lutz Walter 05 Sep 2005
45. Ames E, Hallett WH, Murphy WJ: Sensitization of human breast cancer cells to natural killer cell-mediated cytotoxicity by proteasome inhibition. Clin Exp Immunol 2009, 155:504-I3.

46. Butler JE, Moore MB, Presnell SR, Chan HW, Chalupny NJ, Lutz CT: Proteasome regulation of ULBPI transcription. J Immunol 2009, I82:6600-9.

47. Davies FE, Raje N, Hideshima T, Lentzsch S, Young G, Tai YT, Lin B, Podar K, Gupta D, Chauhan D, Treon SP, Richardson PG, Schlossman RL, Morgan G], Muller GW, Stirling DI, Anderson KC: Thalidomide and immunomodulatory derivatives augment natural killer cell cytotoxicity in multiple myeloma. Blood 200I, 98:2I0-6.

48. Markasz L, Stuber G, Vanherberghen B, Flaberg E, Olah E, Carbone E, Eksborg S, Klein E, Skribek H, Szekely L: Effect of frequently used chemotherapeutic drugs on the cytotoxic activity of human natural killer cells. Mol Cancer Ther 2007, 6:644-54. 